\title{
الموسيقى في شعر محمد الأسمر \\ مستخلص من رسالتّ ماجستير بعنوان: \\ شعر محمد الأسمر ، دراسة فنية
}

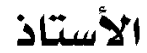

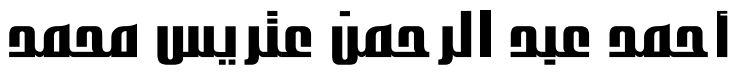 \\ باحث ماجستير -قسه, الدراسات الأديبت \\ كاليت دار العلوه - جامعت الفير الديوه
}

\section{تحت إشراف}

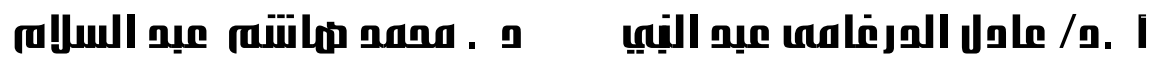

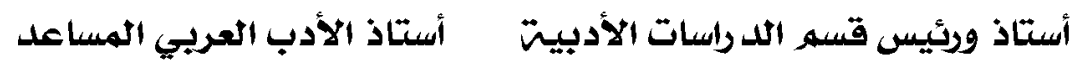

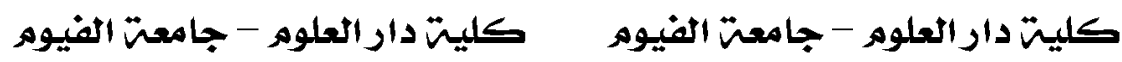

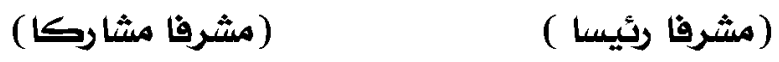


تعد المو سيقى أحد أهم الأدوات في عملية بناء القصيدة العربيــة، والــتيت لا

يكتب النجاح للنص بدوها، فالكلمة عند كوها لفظة مفردة دون مو سيقى تقـــوّم وتعزز مهمتها لا تبلغ بالمتلقي مبلغا ، مهما بلغت من البلاغة والرصانة.

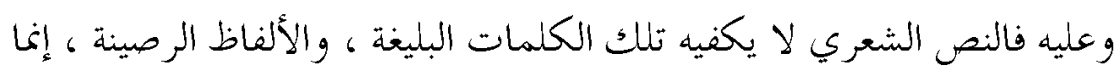
هو بحاجة إلى آلية أخرى ، وأداة تصل بالمتلقي فوق حد الكلمة المفردة وهذه الأداة هي المو سيقى.

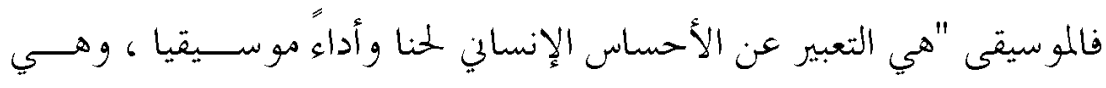

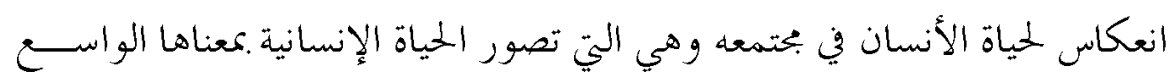

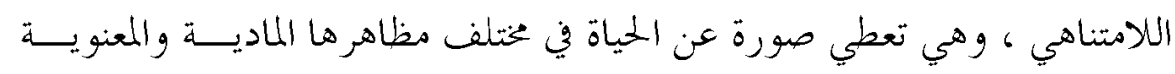

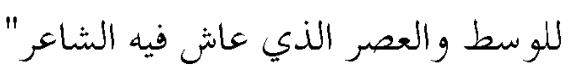

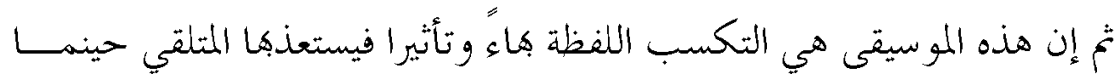

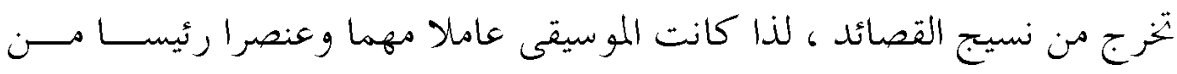
عناصر الفن الشعري ومن أدق مقاييسه النقدية

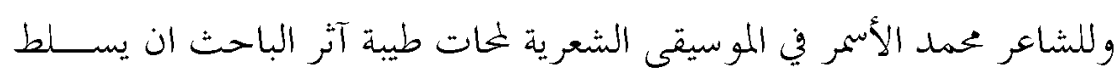
عليها الضوء في هذا البحث.

\section{Abstract}

Music is one of the most important tools in the process of building the Arabic poem, without which success cannot be written for the text.

Accordingly, the poetic text is not sufficient for it with these eloquent words and sober words, but it needs another mechanism, and a tool that connects the recipient beyond the limit of the single word, and this tool is music. 
Music "is the expression of the human sense of melody and musical performance, and it is a reflection of man's life in his society, and it depicts human life in its broad and infinite sense, and it gives a picture of life in its various physical and moral aspects of the medium and era in which the poet lived

Moreover, this music is the acquisition of the word in splendor and influence, so the recipient will be tormented by it when it comes out of the fabric of poems, so music was an important factor and a major element of poetic art and one of its most accurate monetary standards.

And the value of poetry is not complete without the completeness of its poetic image, "because a large part of the aesthetic value of poetry is attributed to its musical image, and perhaps the largest amount of this value is due to the musical image()"

"It is a major factor of influencing the mind of the reader and the listener, that influence which is the most important goal towards which literary criticism aims, and the writer strives as best as he can".

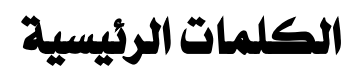

الموسيقى ،في ، شعر، محمد ،الأسمر 


\section{الموسيقى في شعر محمد الأسمر}

\section{المقلمة}

تعد الموسيقى أحد أهم الأدوات في عملية بناء القصيدة العربيــة، والــيت لا يكتب النجاح للنص بدوفا، فالكلمة عند كوها لفظة مغردة دون موسيقى تقـــوّم وتعزز مهمتها لا تبلغ بالمتلقي مبلغا ، مهما بلغت من البلاغة والرصانة.

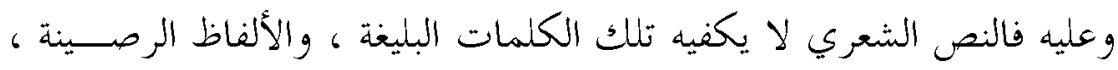

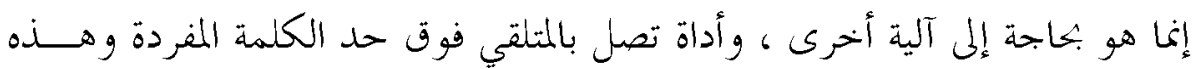
الأداة هي المو سيقى.

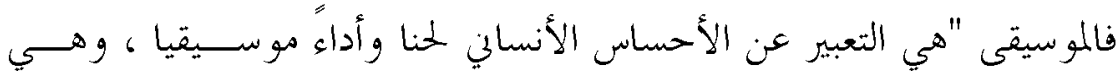

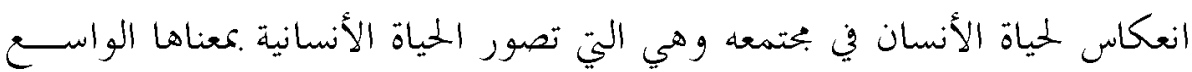

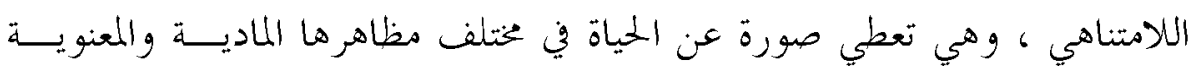

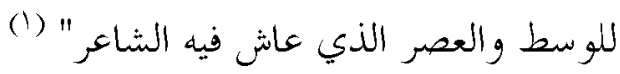

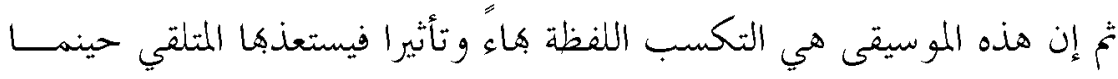

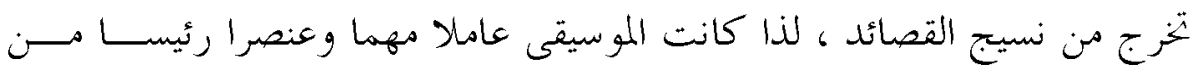

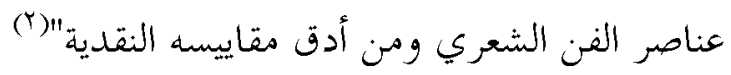

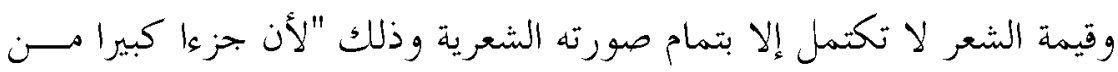
قيمة الشعر الجمالية يعزي إلى صورته الموسيقية ،بل ربما كان أكبر قدر مـن هـــــه

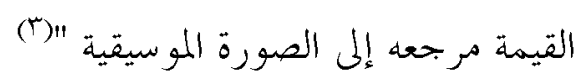
" وهي عامل كبير من عوامل التأثير في نفس القارئ والسامع ذلـــك التــأثير

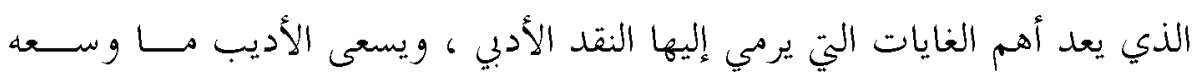

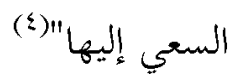
"و تعد الناحية الموسيقية في النص من أهم القضايا التي يولي الشعراء اهتمامهم

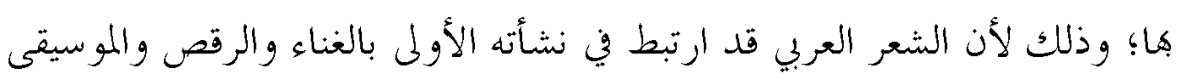
ارتباطاً وثيقاً وقد تطور منذ العصر الجاهلي إلى العصور الإسلامية المختلفة، وقد فئد 


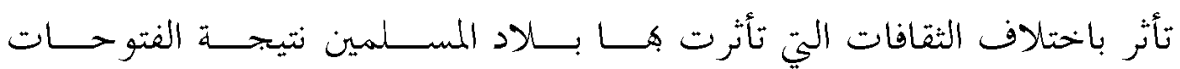
(الإسلامية")

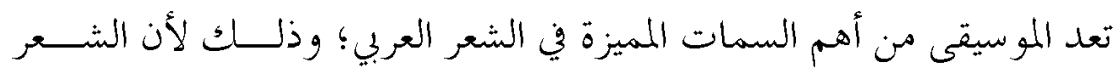
العربي قائم على أساسها، فهو يتكون من مقاطع صوتية منتظمة ومتناسقة فيما بينها

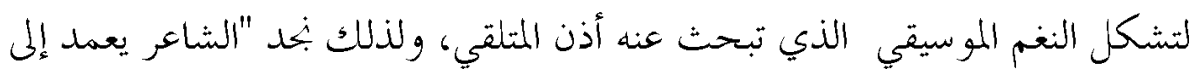

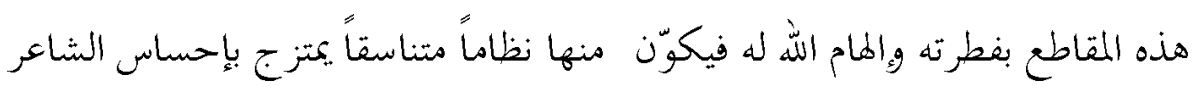

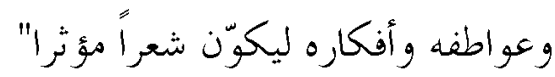

\section{أولا: الوزنة}

يعد الوزن من أهم دعائم الشعر التي لا يمكن الاستغناء عنها بل هو ل "أعظـــم

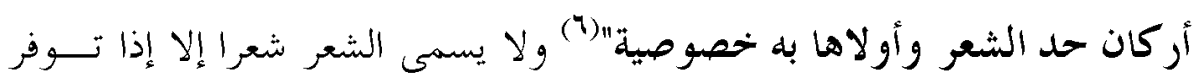

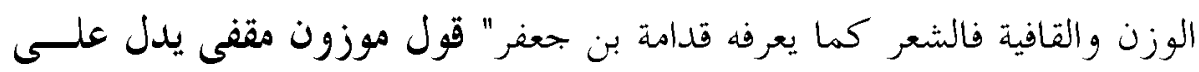

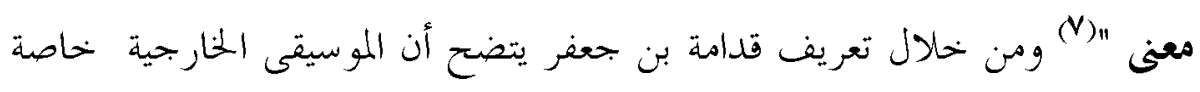

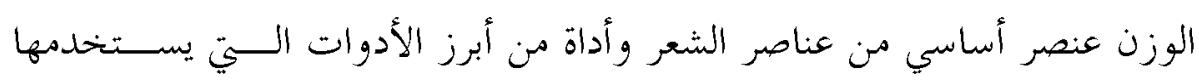
- الشاعر

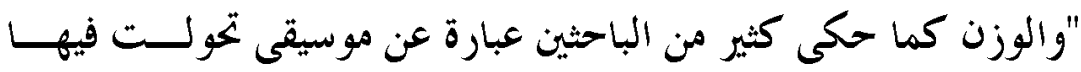

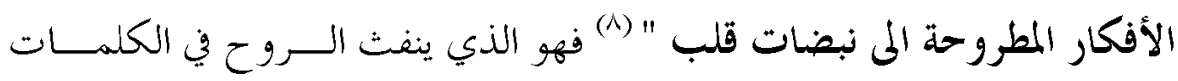

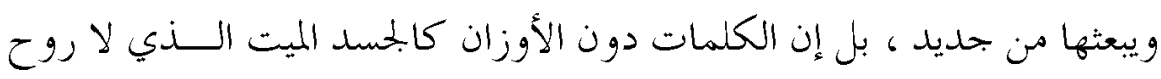
فيه. "والوزن في الشعر كالروح في الجسد إذ هو أول برهان على الشعر ، وأبــرز

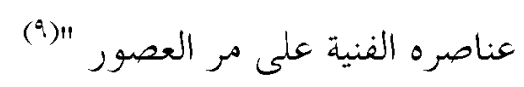

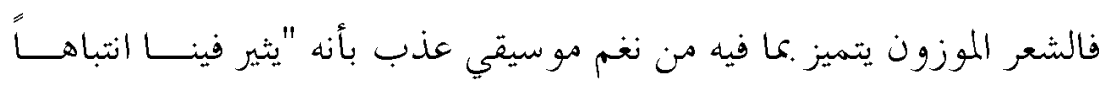

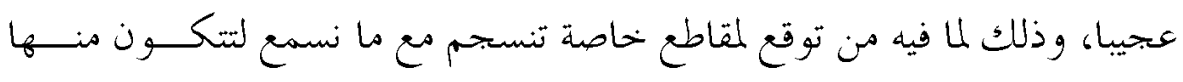




\section{لمـ الموسيقى في شعر محمد الأسمر}

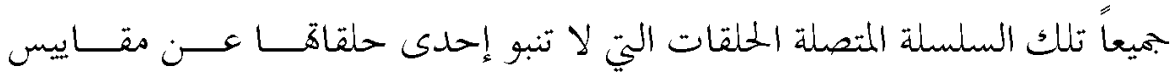

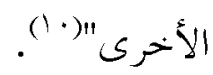

\section{البحور الشعرية}

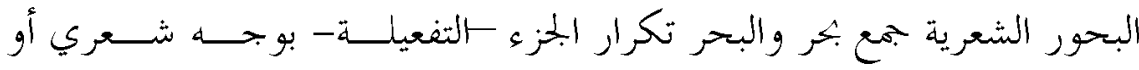

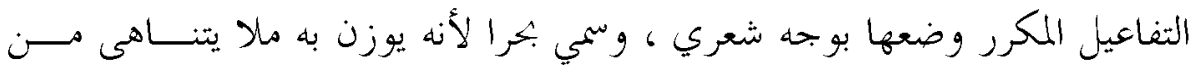
الشعر والبحور تتر كب من التغاعيل الخماسية والسباعية (11)

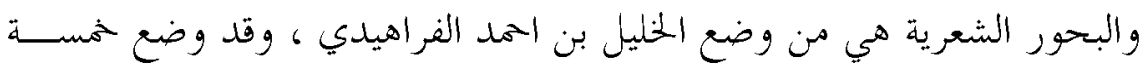
عشر وزناسمى كلا منها بكرا، تشبيها لما بالبحر الذي لا ينتهي بما يغترف منه، في كونه يوزن عليه ما لا يتناهى من الشعر ، ثم جاء تلميذه الأخفش وزاد على أستاذه

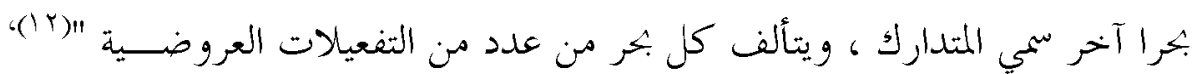

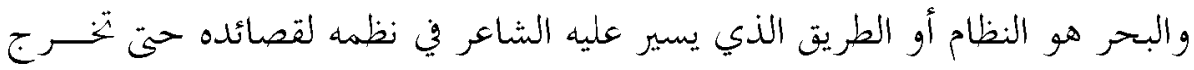

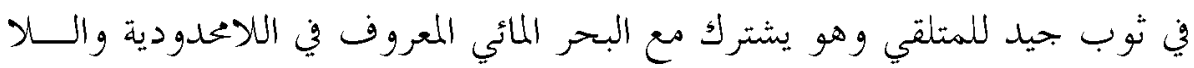
انتهاء ، والبحر العروضي هو النظام الذي تسير عليه القصيدة العربية حتى تخرج في تو ها المحديد الذي يقبله المتلقي.

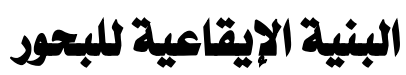

$$
\text { 1 - 1 الطويل الطيل }
$$

وقد استعمل الأسمر الطويل في كثير من قصائده ، بل أخذ المرتبة الثانية مــن

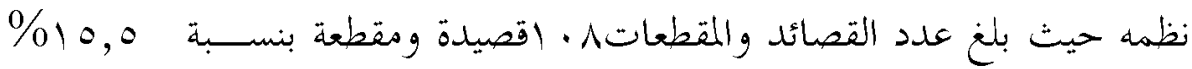

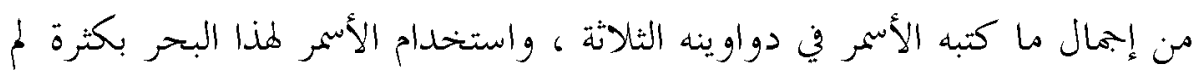
يكن مختصا به أو بعصر إنما كان ذلك عهد الكثيرين قبله من العصور السابقة له .

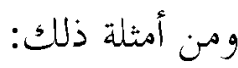




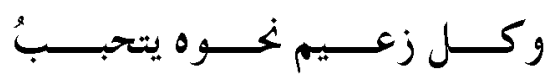

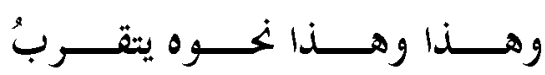

فلما غفى عن واجب المُلك والتوى هوى مثلما يهوى من الأفق كوكبُ

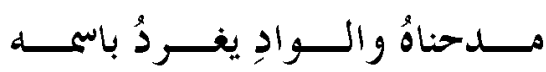

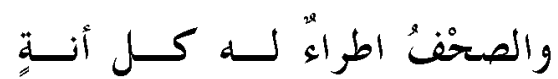

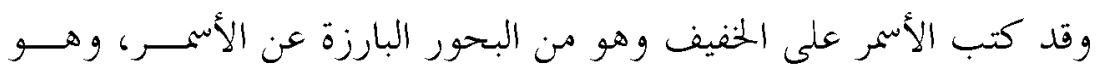

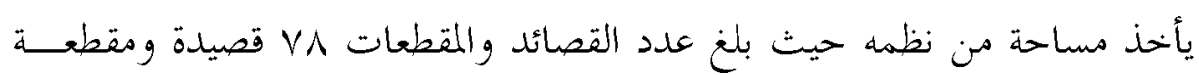
بنسبة Y, 11\% من إبجال ما كتبه الأسمر في دواوينه.

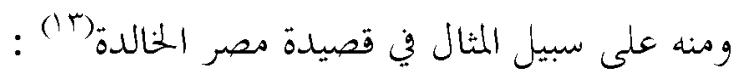

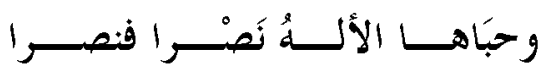

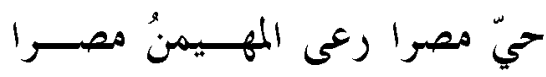

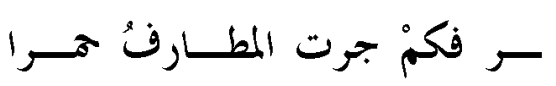

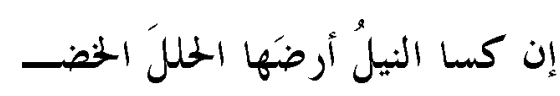

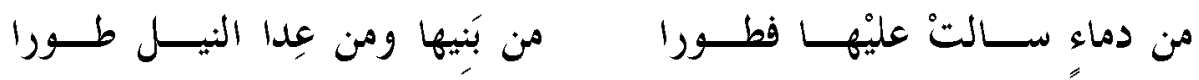

$$
\text { r- البسيط }
$$

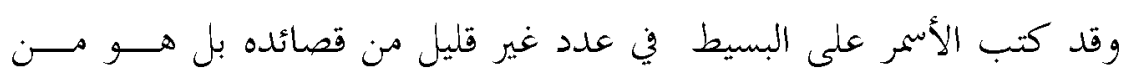

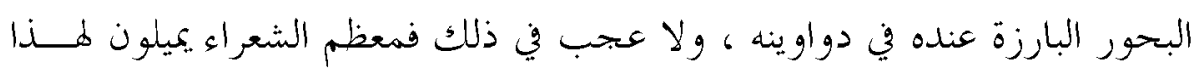

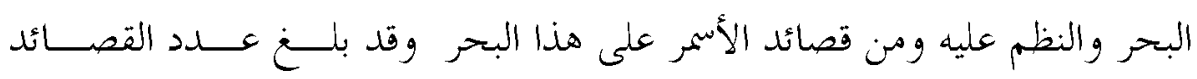

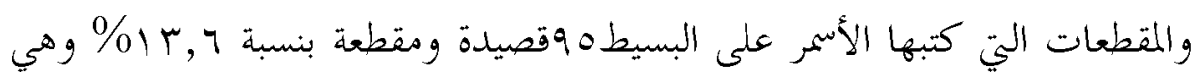
نسبة كبيرة بين البحور التي استخدمها الأمر في نظمه ومحا كتبه الأسمر على البسيط

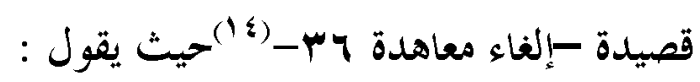

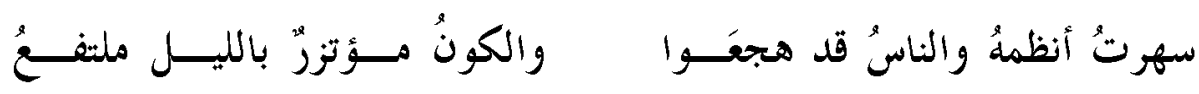

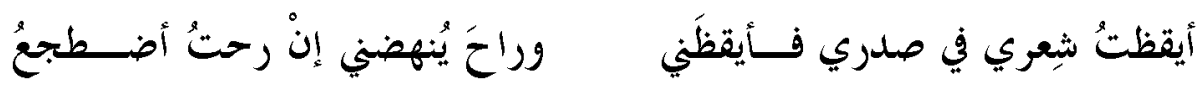




\section{الموسيق في شعر محمد الأسمر}

إذا سهرتُ لــهـ ألفيــتَ ذا ســهرٍ

ع-المتقارب وقد كتب الأسمر على المتقارب غير أنه لم يأخذ منه مساحة كـبيرة

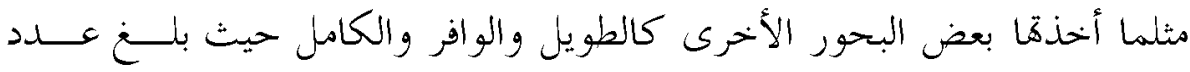

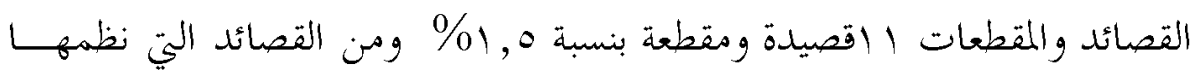

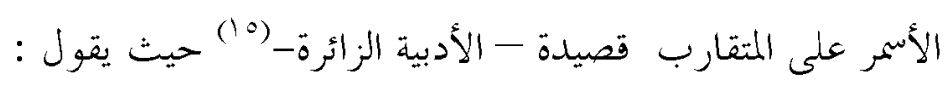

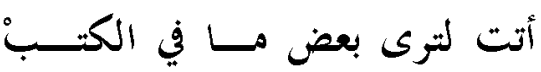

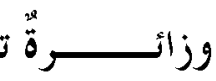

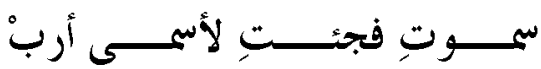

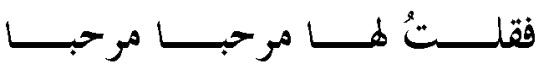

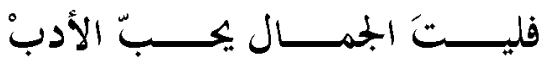

وكــل أديــب يكــب الجمـــال

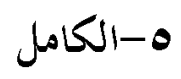

والكامل أكثر البحور استخداما عند الأسمر حيث بلغ عدد القصائد والمقطعـات

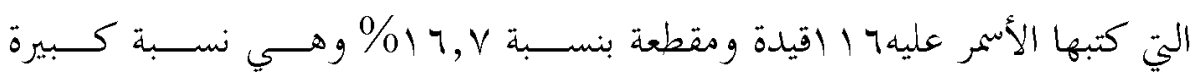

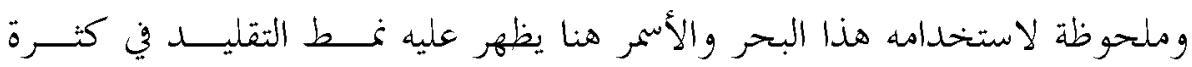
استخدام هذ البحر . البحان.

ومن القصائد التي كتبها الأسمر على الكامل قصيدة - علة العلــلـ (14)

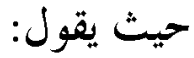

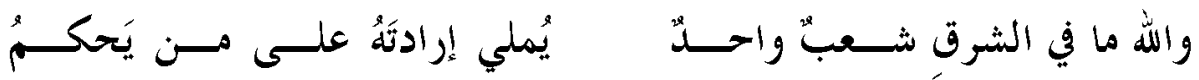

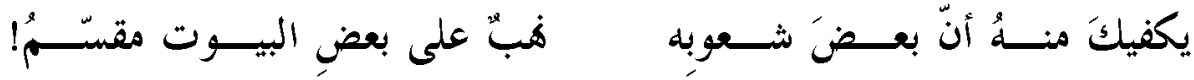

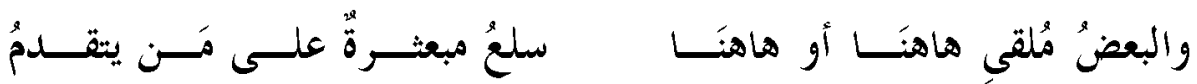


ج-بكر الوافر وقد نظم الأسمر كثيرا على الوافر في دواوينه الثلاثة حتى بلغ عــدد

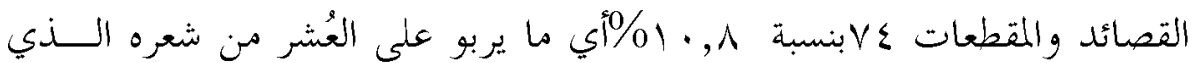
نظمه طول حياته ، وربما شابه الأسمر غيره من الشعراء في كثرة استخدام هذا البحر

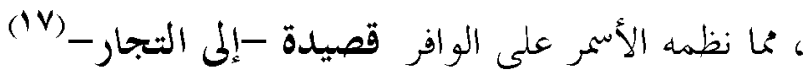

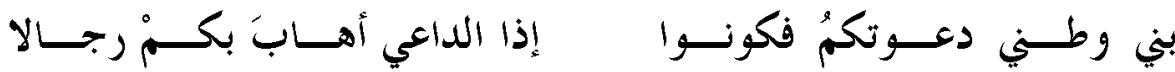

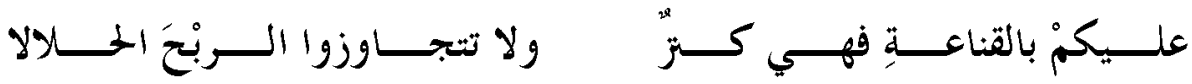

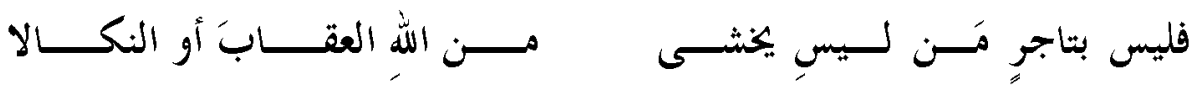

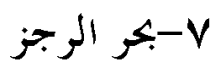

وقد نظم الأسمر على بحر الرجز بـ قصيدة بلغت نسبة ا, بـ\% من شعره وه تعد نسبة قليلة من شعر الأسمر مقارنة باستخدامه لبعض البحور الأخهـرى كـثيرة الاستعمال.

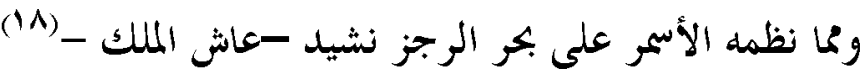
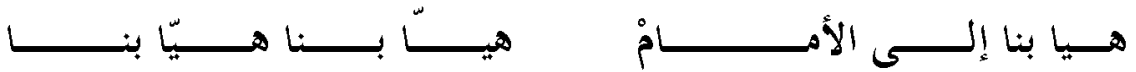

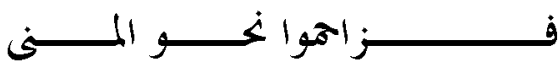

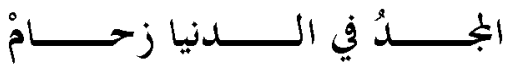

$$
\begin{aligned}
& \text { واسعوا إلى خير الوطن } \\
& \text { م-المزج }
\end{aligned}
$$

وقد نظم الشعراء على الهزج كثيرا في القلديم والحديث إلا أن الأسمر لم يكن مــن الذين أكثروا من النظم عليه فقد بلغ عدد القصائد التي كتاها الأسمر على الهزج 1 الهمبر

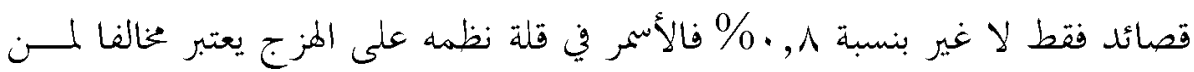
سبقوه في كثرة النظم عليه. 


$$
\text { فمن الهزج قصيدة -بين الحتى والتاريخ - يقول (9) }
$$

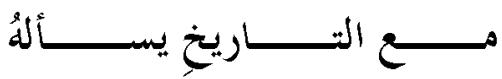

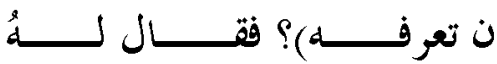

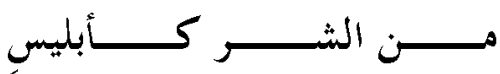
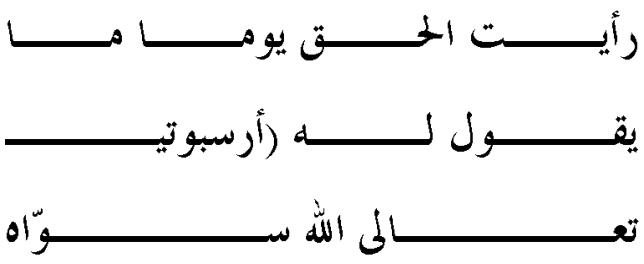

$$
\text { 9-بكر الرمل }
$$

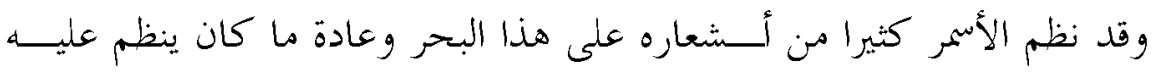

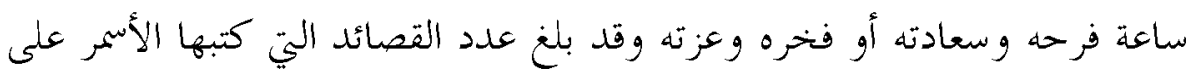

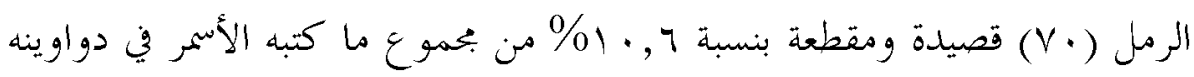
الثلاثة.

$$
\text { ففي قصيدة فرحة العيد(·r) يقول (r)" : }
$$

فالدجى مثـلـل النــهار المثــمس

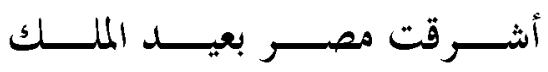

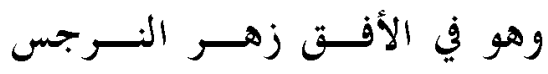

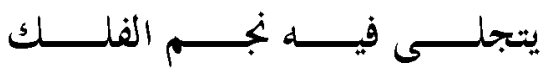

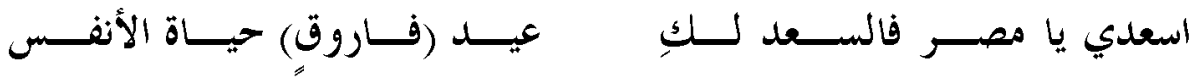

$$
\text { . }
$$

وقد كتب الأسمر على السريع عددا غير قليل من القصائد وإن لم تكن من مثــل التي كتبها على الوافر أو الرجز أو الوافر والرمل ، إلا أنه يلاحظ في دواوينه عددا

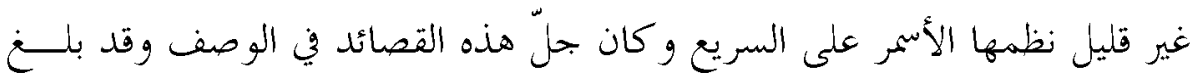

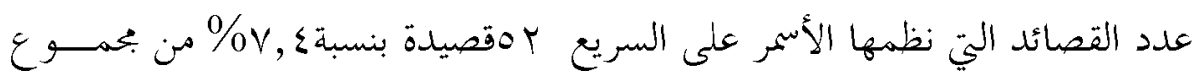
ما كتبه الأسمر في دواوينه الثلاثة . 
ومنها على سبيل المثال قصيدة - مصر وزعمائها - (T) يقول فيها :

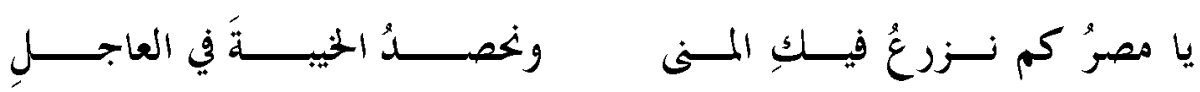

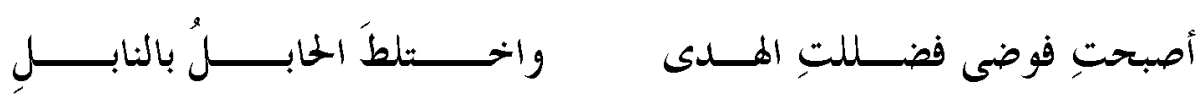

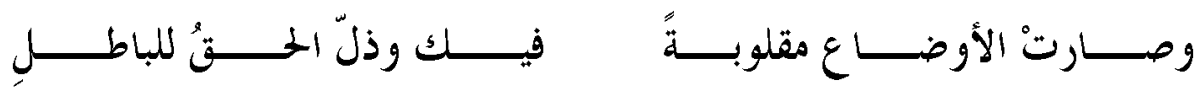

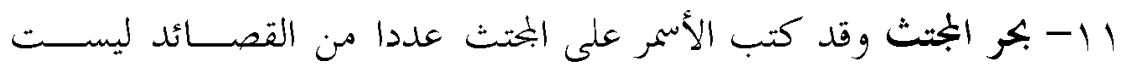

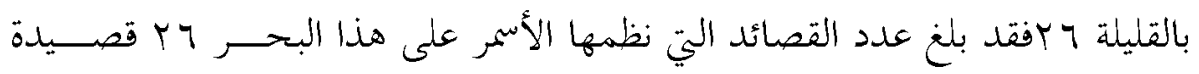
بنسبة r'\% من بمموع ما كتبه الأسمر في دواوينه الثلاثة

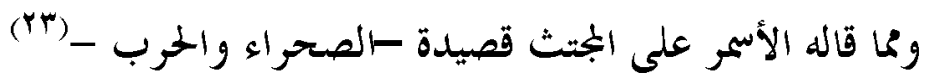

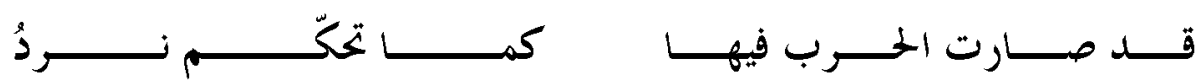
والحهُ

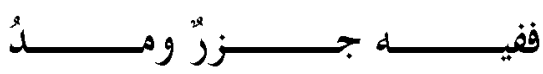

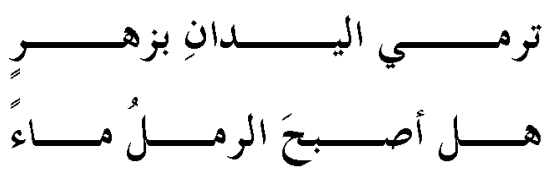

$$
\text { r }
$$

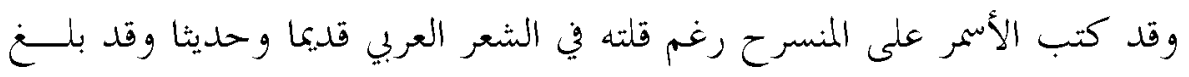

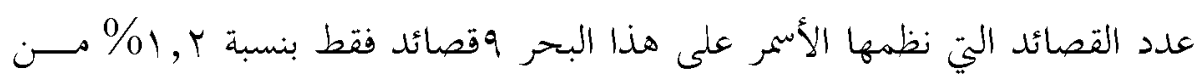
بعموع ما كتبه الأسمر في دواوينه الثلاثة.

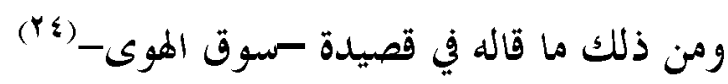

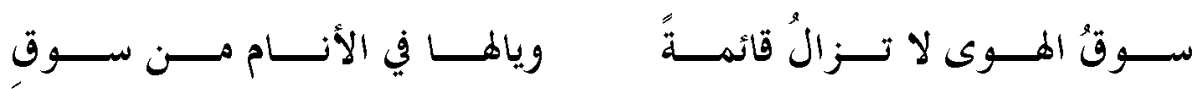

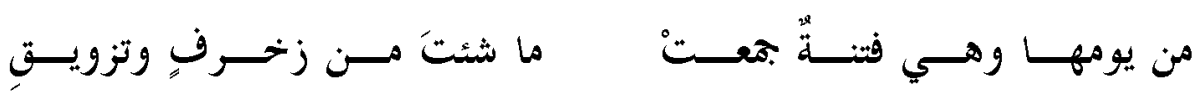

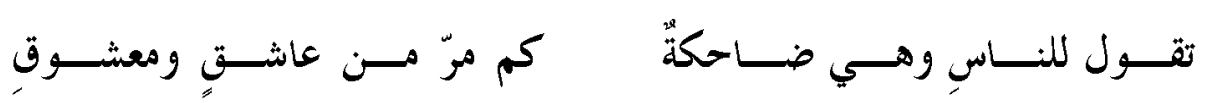




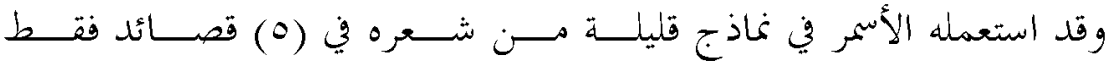

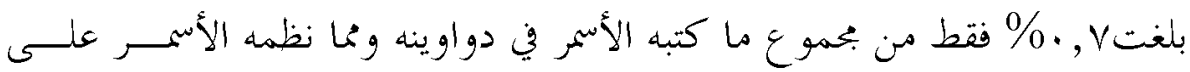

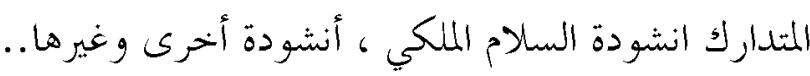
فني قصيدة - أنثودة السلام الملكي - يقول

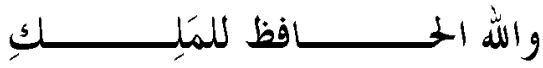

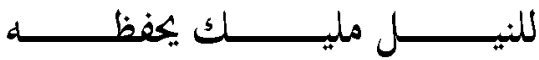

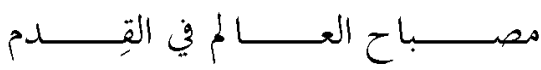

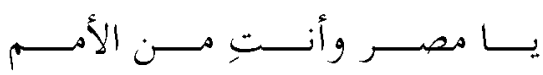

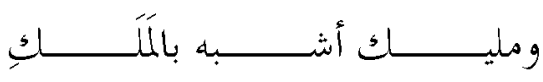

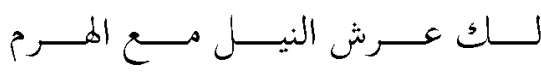

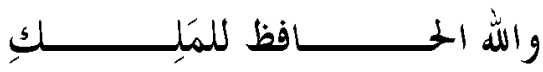

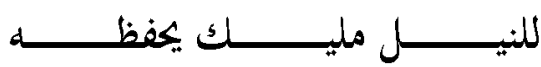
ـ 1 - المقتضب وقد نظم الأسمر قصيدة واحدة على المقتضب في دواوينه الثلاثة جاءت في (ديوان

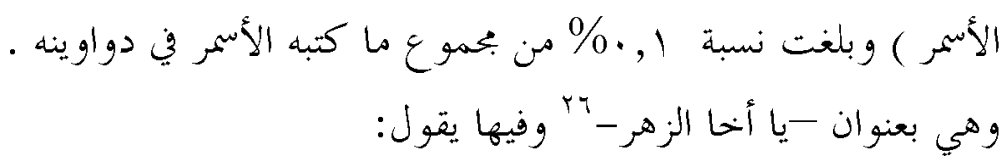<smiles>[3H][Al][As][3H]</smiles>

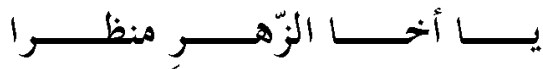

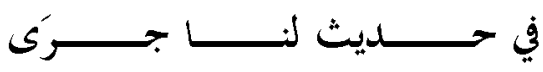

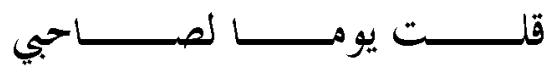

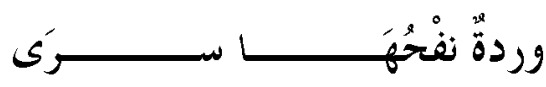

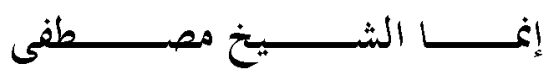

إحصاء للبحور التامة الوارة عليها قصائد ومقطعات محمد الأسمر

\begin{tabular}{|c|c|c|c|c|}
\hline ملاحظات & النسبة المئوية & مرات الإستخدام & البحر & b \\
\hline & $\% \backslash 7, \mathrm{~V}$ & 117 & الكامل & 1 \\
\hline & $\% \backslash 0,0$ & $1 \cdot \lambda$ & الطويل & r \\
\hline & $\% \backslash r, 7$ & 90 & البسيط & r \\
\hline
\end{tabular}

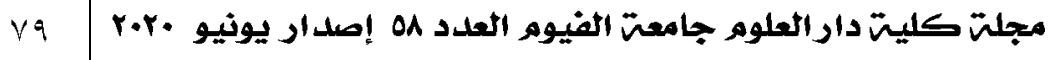


الموسيقى في شعر محمد الأسمر

\begin{tabular}{|c|c|c|c|}
\hline$\% \backslash 1, r$ & $\vee \wedge$ & الحفيف & $\varepsilon$ \\
\hline$\%$ & $V \leq$ & الو افر & 0 \\
\hline$\% 1 \cdot, 7$ & $v$. & الرمل & 7 \\
\hline$\% \vee, \varepsilon$ & or & السريع & V \\
\hline$\% 4,1$ & $\varepsilon r$ & الرجز & $\wedge$ \\
\hline \% r'r & $r q$ & المختث & 9 \\
\hline$\% 1,0$ & 11 & المتتارب & 1. \\
\hline$\% 1, r$ & $q$ & المنسرح & 11 \\
\hline$\% \cdot, \wedge$ & 7 & الهزج & Ir \\
\hline$\% \cdot, v$ & 0 & المتدارك & Ir \\
\hline$\% \cdot, 1$ & 1 & المقتضب & $1 \varepsilon$ \\
\hline
\end{tabular}

إحصاء للبحور الجزووة الواردة عليها قصائد ومقطعات محمد الأسمر

\begin{tabular}{|c|c|c|c|c|}
\hline النسبة المئوية من & إجمالية الألوئوية من & مرات الإستخدام & البحر & 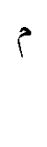 \\
\hline$\% \wedge \neg, \varepsilon$ & $\% 0, r$ & $r v$ & الرجز & 1 \\
\hline$\%$ & $\%$ & $r V$ & الرمل & r \\
\hline$\% \backslash \vee, r$ & $\% r, \wedge$ & $r$. & الكامل & r \\
\hline$\% \leq, 0$ & $\% \cdot, \Sigma$ & r & الو افر & $\varepsilon$ \\
\hline$\% r$. & $\% \cdot, 1$ & 1 & المتدارك & 0 \\
\hline
\end{tabular}

\section{ثاذيا القماضية}

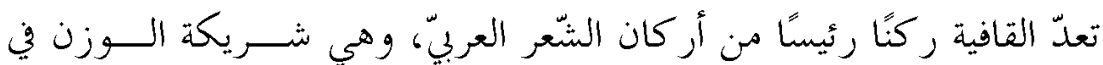

الاختصاص بالشّعر، وهما ميزّ القدماء الشّعر عن النّتر .وللقافية قيمة موسيقيّة

في مقطع البيت وتكرارها يزيد في وحدة النّغم ....و كلماها - في الشّعر الجليّد - 


\section{الموسيق في شعر محمد الأسمر}

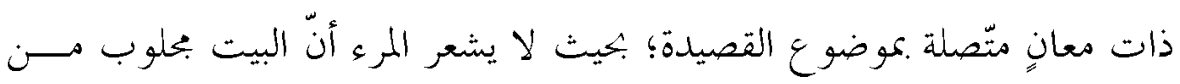

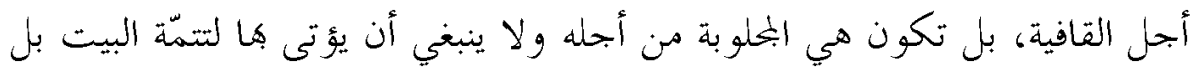

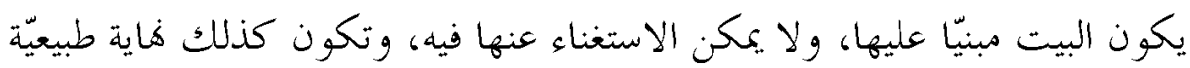

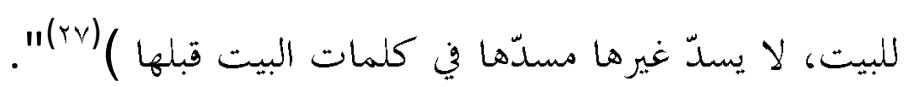

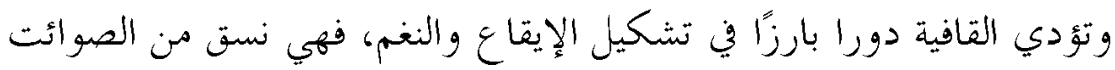

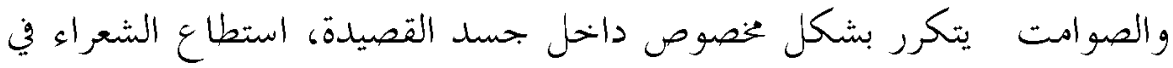
العصر الحديث أن يفتئتوا على صرامتها التي كانت ثتثل كواهلهم وبتحسبرهم في

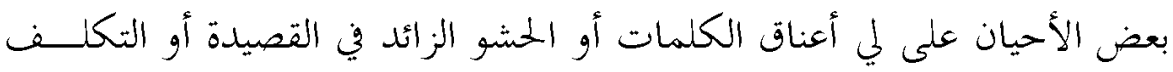

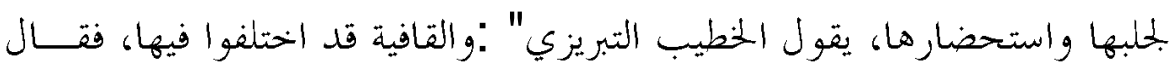

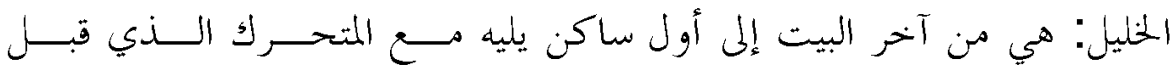

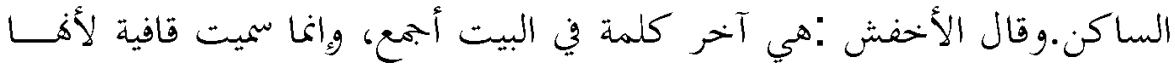

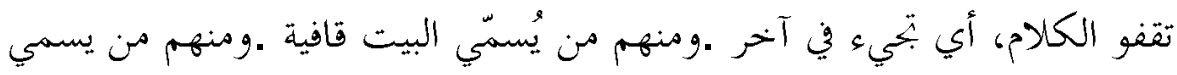

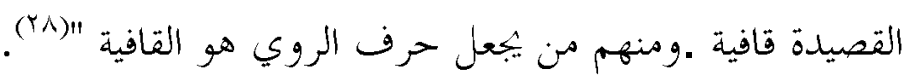

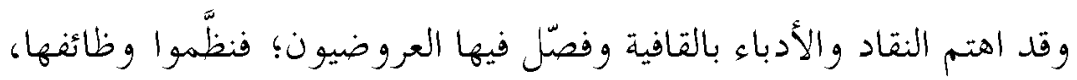

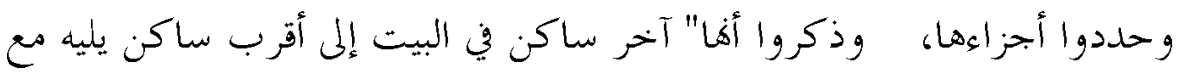

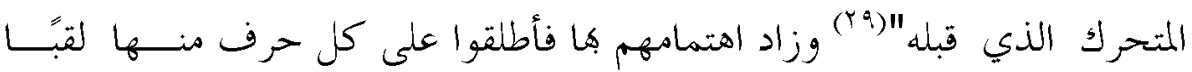

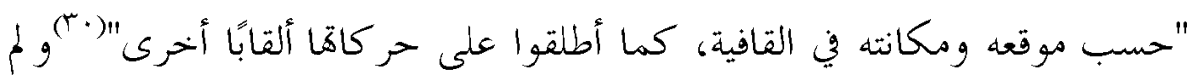

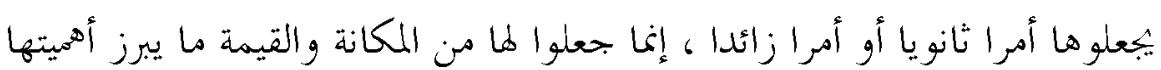

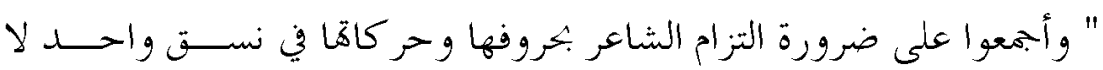

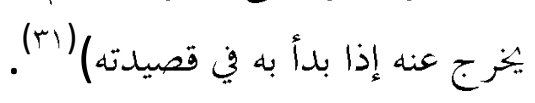

وهي ركن أساسي من أركان البيت الشعري فهي ((شريكة الوزن في

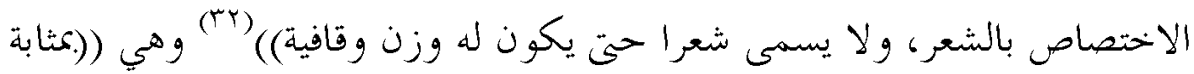

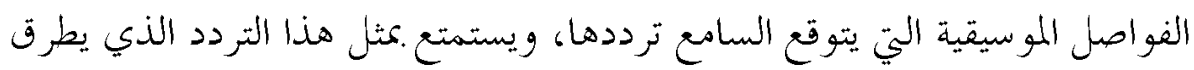


الاذان في فترات زمنية مختلفة)) (Tr()وهي تساعد كثيرا على اكتمال النص الشعري من جوانبه الإيقاعية، الذي يعطي للقافية هذا القدر من الاهتمام و الخطورة (موقعها المتميز في آخر البيت و التناغم الصوتي الذي تحتوي عليه ،تفرض على

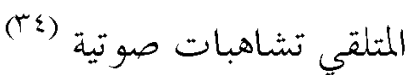

\section{القافية (لخة الخبان}

من قفا ،يقفو ،قفوا، و قافية ،و (هوأن يتّبع شيئا، و قفوته ، أقفوه ،قفواه

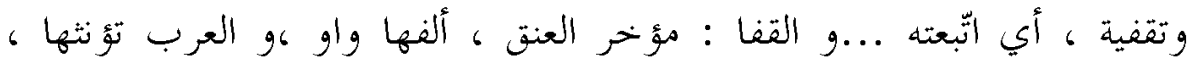

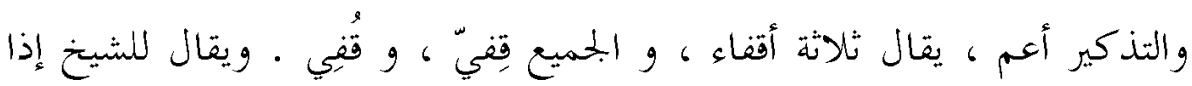
هرم: ردّ على قفاه ، وردّ قفاً.... و تقفىته بالعصا ، أي ضربت قفاه ها واستقفيته بعصا ، إذا جئته من

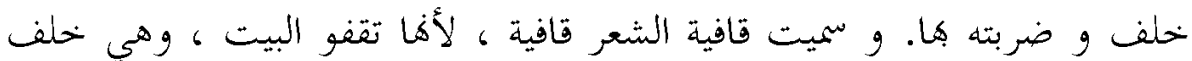
البيت كله... (ro)

\section{القافية اصطلاحما:}

قد يظن البعض أن تحديد القافية أمرا سهل ميسور، لكن المتتبع لأقوال النقاد قديما وحديثا يبجد فرقا كبيرا و بو نا عظيما بين أقوال النتاد في تحديد مفهوم القافية . فالقافية عند مؤسس عنم العروض -الخليل بن أحمد الفراهيدي - (من آخر

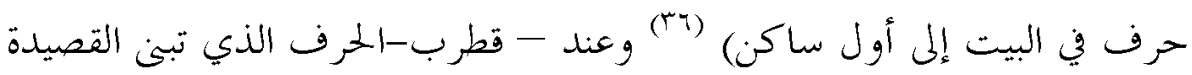
عليه، وهو المسمى رويا، أمّا-ابن كيسان-فقد عرفها بأها كل شى لزئ لزمت إعادته في آخر البيت.

وقد علق ابن جني قائلا: والذي يثبت عندي صحته من هذه الأقوال هو قول (TV) (الخنيل)

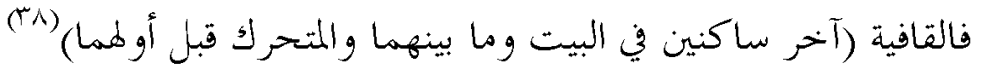


ولأن كانت التعريفات التي وضعت للقافية كثيرة ومتعددة، فما زال تعريف

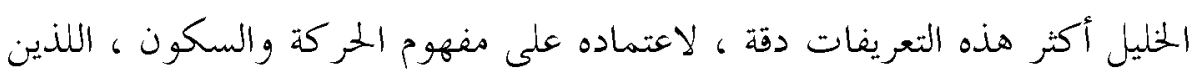
اعتمد عليهما في نظامه العروضي وبناء كيانه الإيقاعي الذي حدد من خلاله القافية "(ب.)

\section{أذواع الثقاظية}

القو افي نوعان :

1- القافية المقيدة: ((وهي القافية التي يكون رويها ساكنا))(•) وهذا النوع مــن القوافي قليل الانتشار في الشعر العربي لأن الحركة أكتر حظا في اللغة العربية من العن

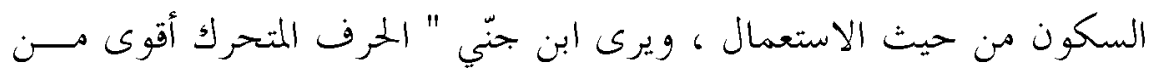

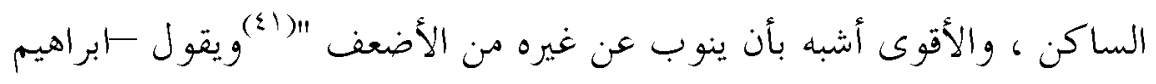

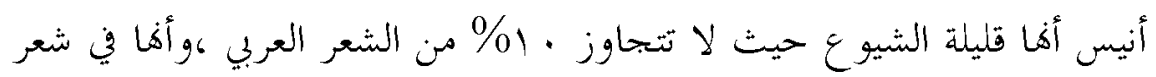

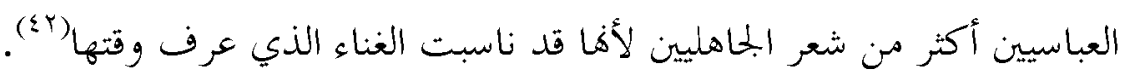

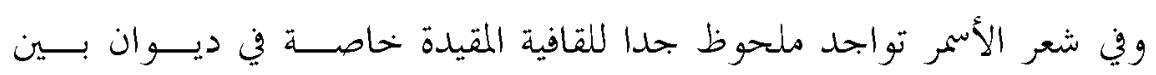
الأعاصير تظهر في بعض القصائد في دواوينه الثلاثة ومن أمثلة ذلك . ..

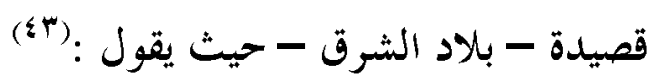
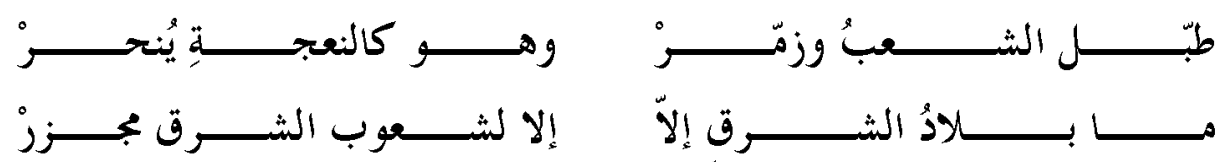

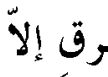
لادُ الثر
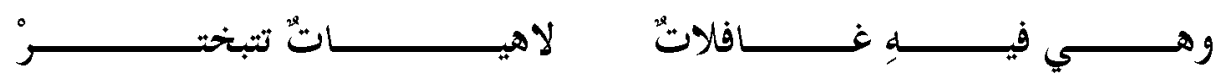

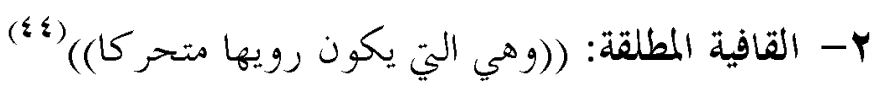

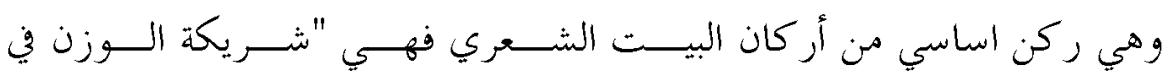

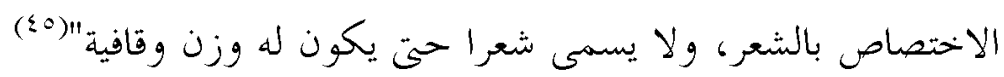




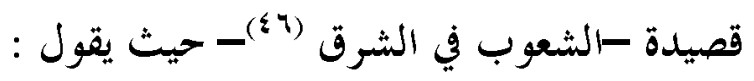

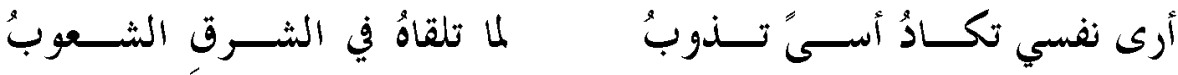

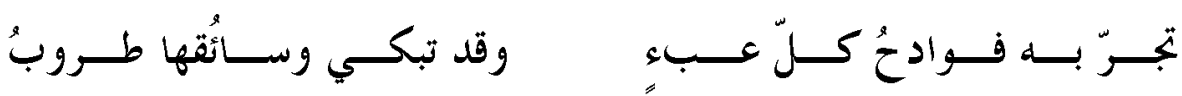

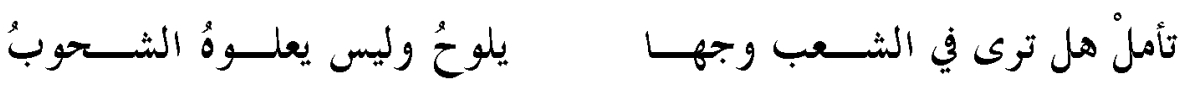

والأسمر كغيره من الشعراء بلغت القافية المطلقة الغالبية العظمى مــن شـــره حيث أن الشعراء يجدون في حركة الحرف المحال الأوسع في ترجمة بتربته الشعرية. وإذا تتبعنا نظام القافية عند الأسمر نرى أنه قد نوع في القافية ومن هذا التنوع :

$$
\text { المزدوج: }
$$

وهو كما يقول إبراهيم أنيس " وفيه تتميز القافية مع كل بيـت ، و ويراهـي

الناظم في المزدوج أن تكون الأبيات مصرعة ،فقافية الشطر الأول هي نفس قافيسـة (sv)" الشطر الثاني

وقد وجد المزدوج في شعر الأسمر وإن لم يكن بكثرة ففي قصيدة بعنـــوان -

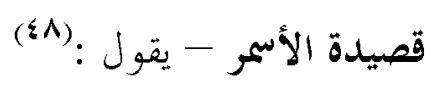

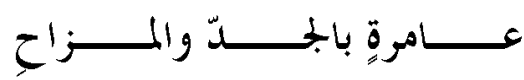
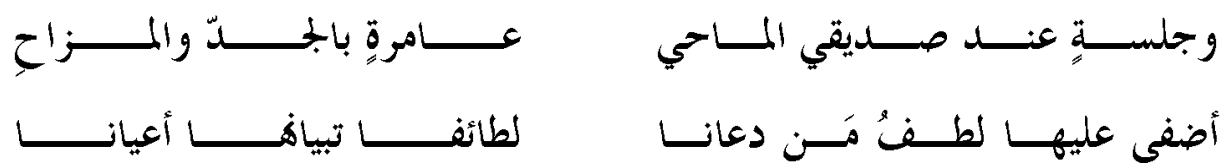

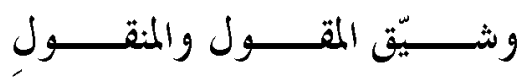

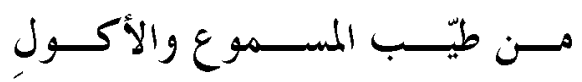

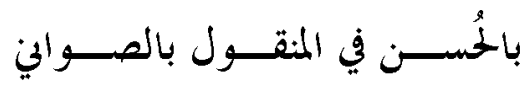

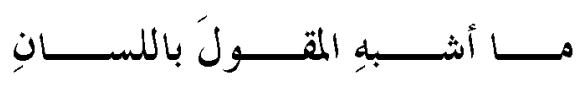

فالأسمر عمد إلى نظم سهل يسير لا يكلفه مشقة وهو ما يناسب الحال التي قيلت فيها هذه القصيدة فهذا النظم لا يكلف الشاعر شيئا من التعب والمشقة. 


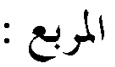

نوع من الشعر " الذي يقسم فيه الشاعر قصيدته إلى أقسام يتضمن كل قسم منها

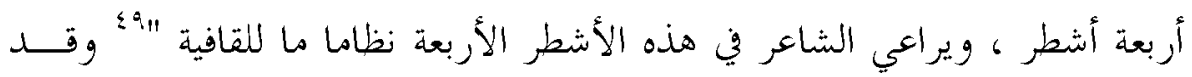

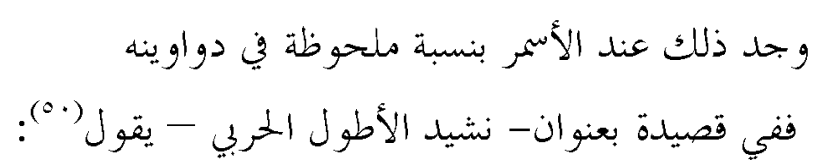

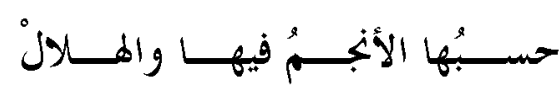

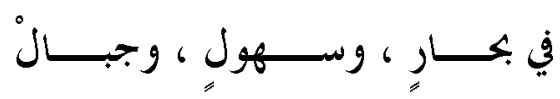

إن دعا الداعي ونادتنــــ الجـــدوذ

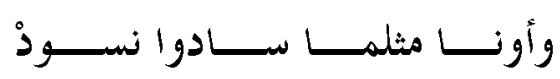

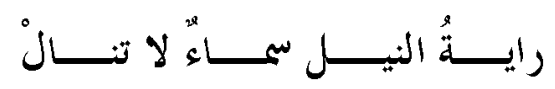

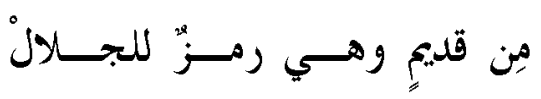

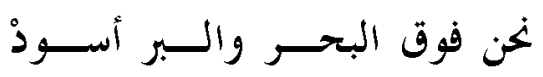

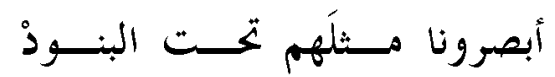

والدوبيت في القافية قليل الإستخدام عند العرب حتى قال إبراهيم أنيس "ولا

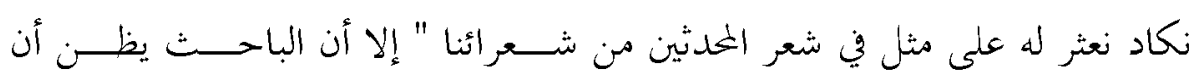

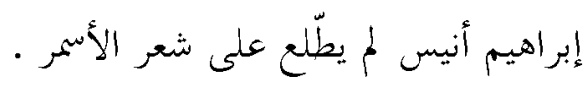

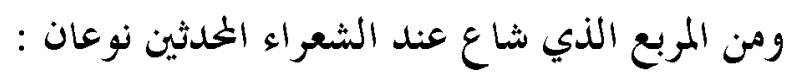

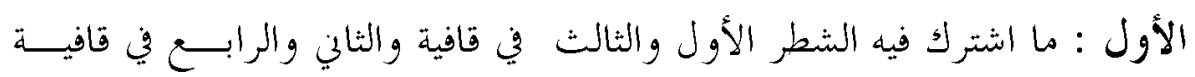

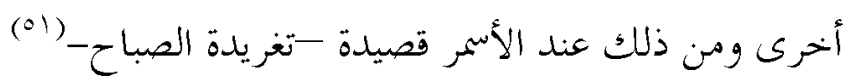

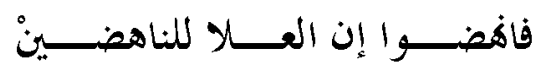

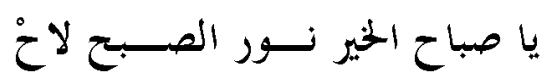

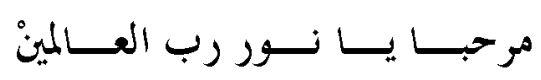

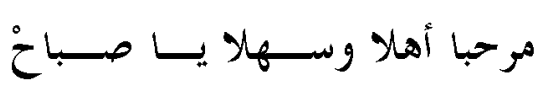
وفي قصيدى -لص القاهرة -يقول (or) حائر أ لم يـــدر مــــاذا يســـــ

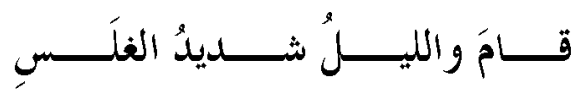
حية تسعى ، وســهما يـــرقو

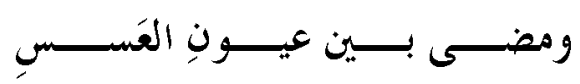


الثابي :وهو أن تتكرر قافية الثطر الرابع مع كل قسم من أقسام المربعات

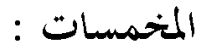

وهو أن " يقسم الشاعر مقطوعته إلى أقتسام يتضمن كل قسم منـــها خمســـة

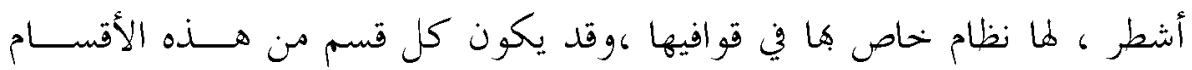

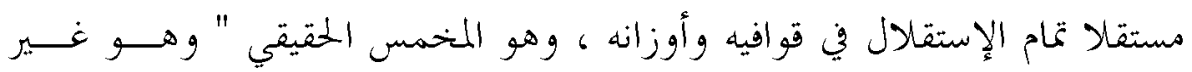

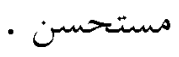
أما الذي استحسنه الشعراء الخدثون واستوعبوا مو سيقاه هو "الذي تتكـــرر

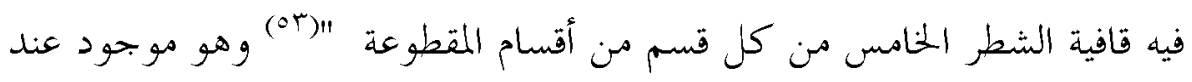

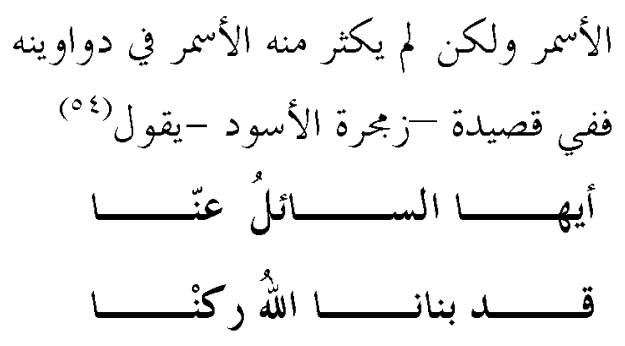
عشت يا معر وعشنا
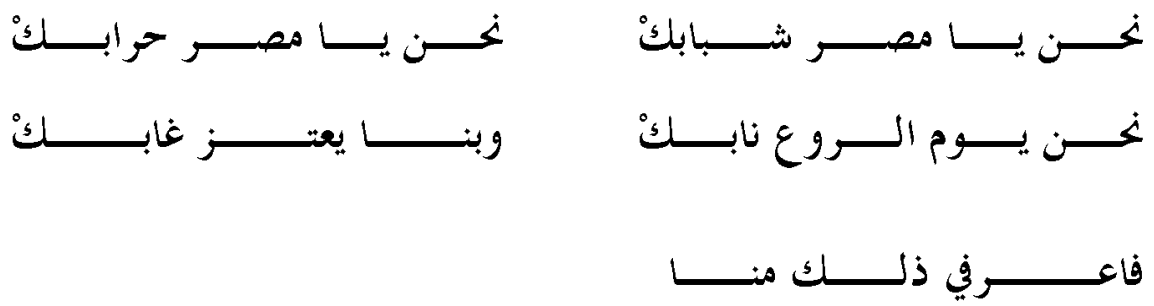

المسموط:

قال إبراهيم أنيس" يضع الشاعر لأوزانه وقو افيه نظاما خاصا يراعيه في كل أقسام المقطوعه "

ومحا قاله الأسمر من هذ النوع قصيدة بعنوان -أنطون باشا الجميل -فيقول (00) 


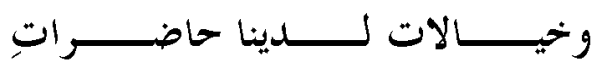

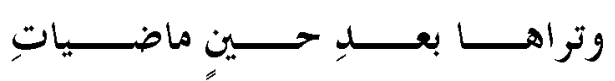

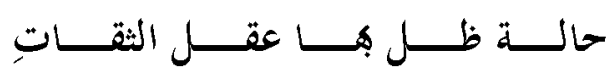

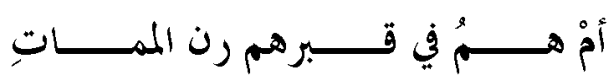

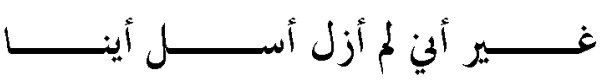

\section{أين أحباب لنا يا قــوم أينا؟

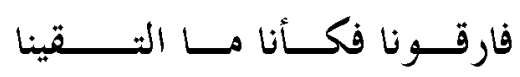 \\ فارقُونا غـــير تلــك الــــكريات

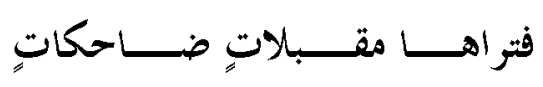

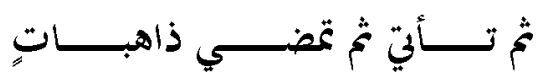 فهل الأحبــاب عـــادوا للحيـــاة

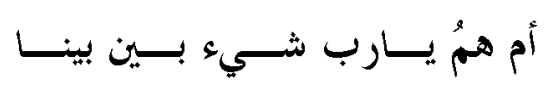 أين أحباب لنا يا قــوم أينا؟

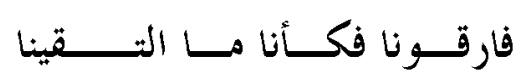

ففي هذه القصيدة جمع الأسمر بين الدوبيت والمسمط والموشحة منا يلفت النظر

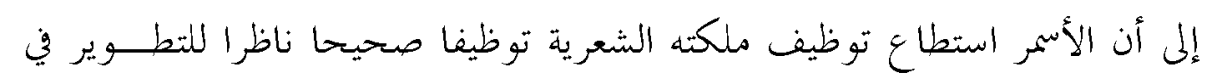

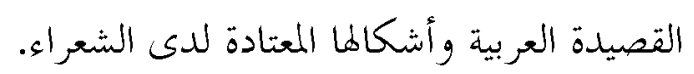
إحصاء حروف الروي في قصائد الأسمر

\begin{tabular}{|c|c|c|c|c|}
\hline ملاحظات & النسبة المئوية & مرات الاستخدام & حرف الروي & 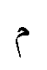 \\
\hline & $\% 10,0$ & 11. & الراء & 1 \\
\hline & $\% \backslash r, q$ & 99 & اللام & r \\
\hline & $\% \backslash r, 1$ & $\wedge \uparrow$ & النون & r \\
\hline & $\% \backslash 1, \varepsilon$ & $\lambda 1$ & الباء & $\varepsilon$ \\
\hline & $\% 1$. & VI & الدال & 0 \\
\hline
\end{tabular}


الموسيقى في شعر محمد الأسمر

\begin{tabular}{|c|c|c|c|}
\hline$\%$ r'v & $0 \leq$ & الميم & 7 \\
\hline$\% \leq, 7$ & rr & الممزة & V \\
\hline$\% 0^{\prime} \varepsilon$ & rr & القاف & $\lambda$ \\
\hline$\% \leq, 9$ & rq & التاء & 9 \\
\hline$\%$ r, $q$ & YI & العين & 1. \\
\hline$\%$ r,o & $1 \wedge$ & الفاء & 11 \\
\hline$\% r, r$ & 17 & السين & Ir \\
\hline$\% r, r$ & 17 & الياء & Ir \\
\hline$\% 1,0$ & 11 & الضاء & $1 \varepsilon$ \\
\hline$\% 1,1$ & $\lambda$ & الكاف & 10 \\
\hline$\% 1,1$ & $\lambda$ & اء dاs & 17 \\
\hline$\% \cdot, 0$ & $\varepsilon$ & الشين & iv \\
\hline$\% \cdot, \varepsilon$ & $r$ & الذال & $1 \lambda$ \\
\hline$\% ., \leq$ & $r$ & الحاء & 19 \\
\hline$\% \cdot$, & $r$ & الواو & $r$. \\
\hline$\% \cdot, r$ & $r$ & الصاد & $Y_{1}$ \\
\hline$\% \cdot, 1$ & 1 & الجليم & YY \\
\hline
\end{tabular}

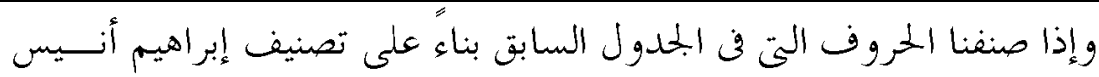

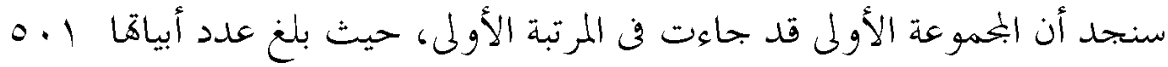

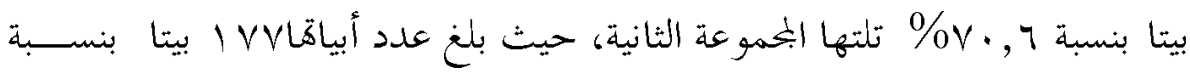
I \& \& , 9

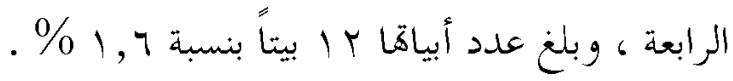


فالأسمر تقليدي في استخدام حروف الروي لم يخرج عن الطريقة المألوفة لدى الشعراء قديما ،فقد سار على فه من سبقوه في استخدام حروف الروي في قصائده إذ تظهر عليه سمات التقليد واضحة جلية في ذلك

$$
\begin{aligned}
& \text { ثبت المصادر والمراجع } \\
& \text { أولا المصادر } \\
& 1 \text { - عمد الأسمر }
\end{aligned}
$$

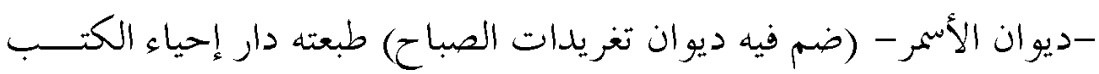

$$
\text { العربية - القاهرة } 1901
$$

$$
\begin{aligned}
& \text { تغريدات الصباح طبعته - دار المعارف - القاهرة 0ـ } 19 \\
& \text { بين الأعاصير - طبعته مطابع فن للطباعة - القاهرة } 19.99 \\
& \text { ثانيا: المراجع }
\end{aligned}
$$

1- إبراهيم علي أبو الخشب: تاريخ الأدب العربي -الهيئة المصرية العامة للكتــاب

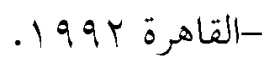

Y-إبراهيم أنيس موسيقى الشعر طـدار القلم بيروت

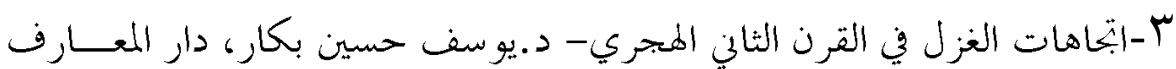

$$
\text { مصر. }
$$

ك -ابن الأثير المثل السائر في أدب الكاتب والشاعر تحقيق د/احمد الحو في والدكتور

$$
\text { بدوي بطانة،در هضة مصر، القاهرة }
$$

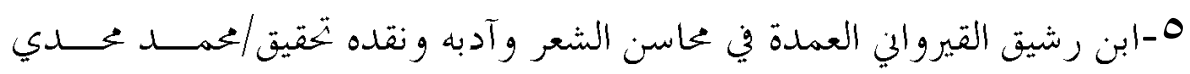

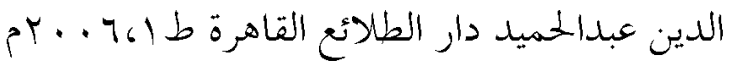

$$
\begin{aligned}
& \text { 7-إحسان عباس فن الشعر طلبيروت } 1900
\end{aligned}
$$

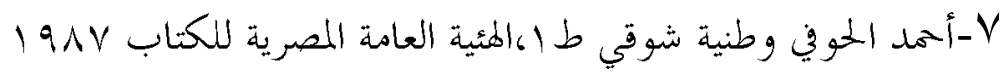

$$
\text { 1أحمد كشك }
$$


من وظائف الصوت اللغوي طب دار المعارف القاهرة

$$
\text { القافية تاج الأيقاع طل اله دار غريب القاهرة }
$$

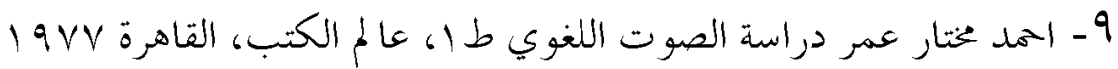
• 1 - احمد هيكل تطور الأدب الحديث في مصر طلادار المعارف القاهرة

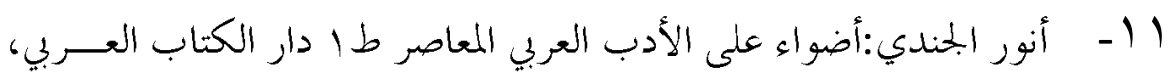

$$
\text { 1979 }
$$

Y ا - أنيس المقدسي: الاتجاهات الأدبية في العالم العربي الحديث، ط اه بيروت،

$$
\text { جابر عصفور } 190 \mathrm{r}
$$

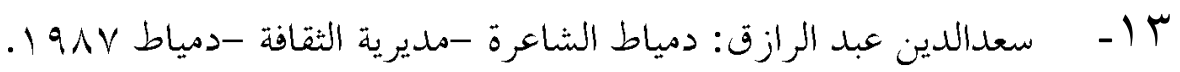

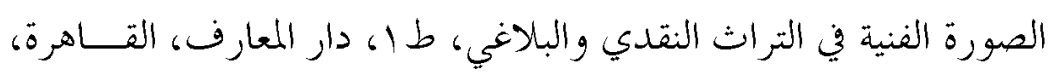

$$
191 .
$$

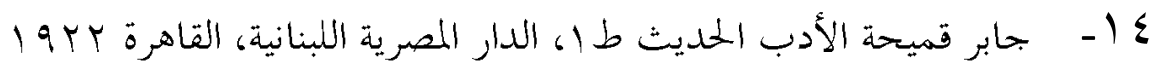
1 - - جورجي زيدان:تاريخ آداب اللغة العربية طا دار الهلال، القاهرة

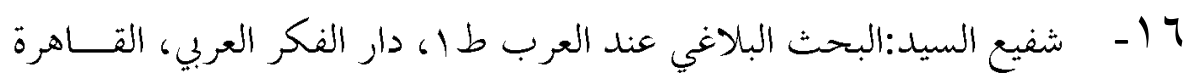

$$
\text { I I V V - شكري عياد }
$$

موسيقى الشعر العربي طل دا، دار المعرفة القاهرة، 1971 1971 البطل في الأدب والأساطير طاله دار المعرفة، القاهرة 1907

$$
\text { 11 ا - موقي ضيف }
$$

هالبارودي رائد الشعر المديث طه دار المعارف، القاهرة

$$
\text { شوقي شاعر العصر الحمديث، طجدار المعارف القاهرة }
$$

هالأدب العربي المعاصر في مصر، طس دار المعارف، القاهرة 


\section{الموسيقى في شعر محمد الأسمر}

$$
\text { - } 19
$$

• بلاغة الخطاب وعلم النص، سلسة عالم المعرفة، عدد ع ؟ب، الكويت

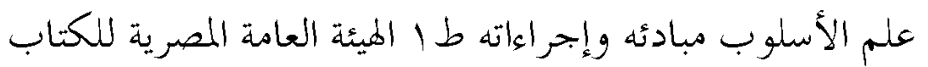

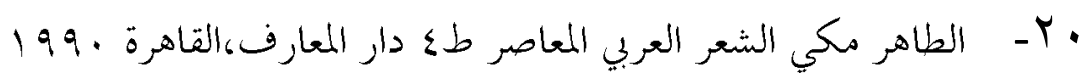

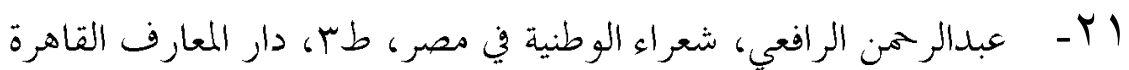

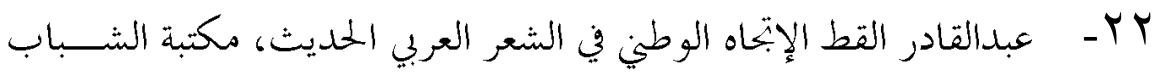

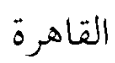

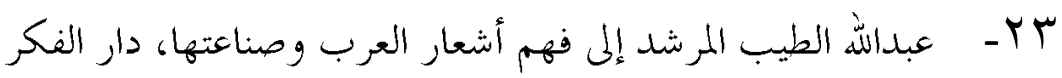

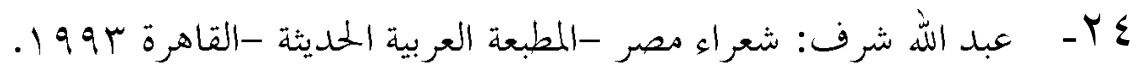

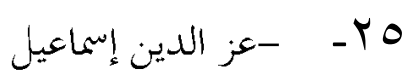

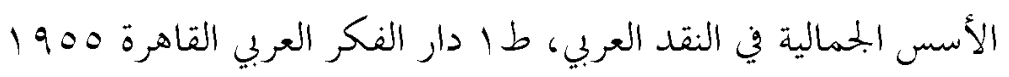

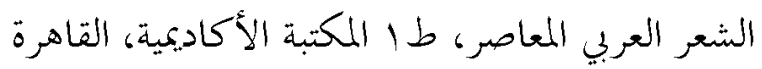

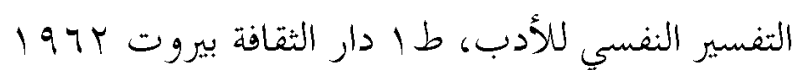

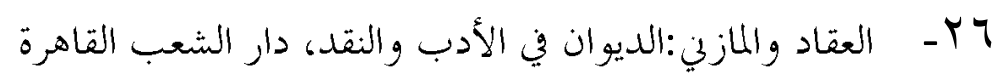

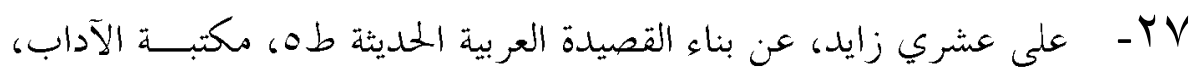
r...

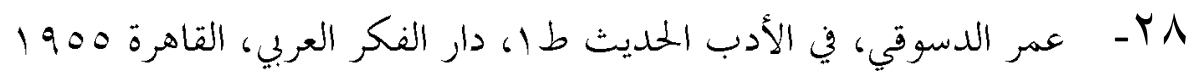

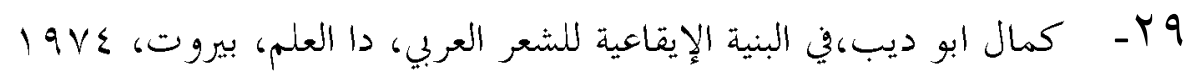

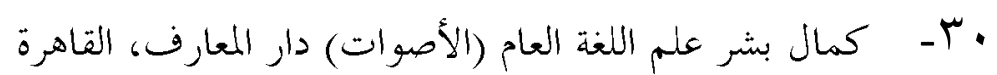

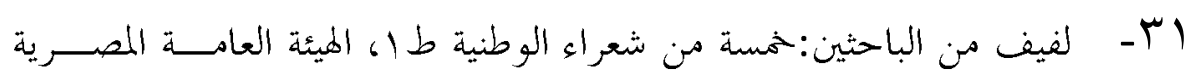

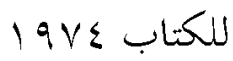

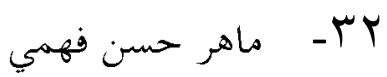


تطور الشعر العربي الحديث في مصر خلال النصــف الأول مــن القــــن

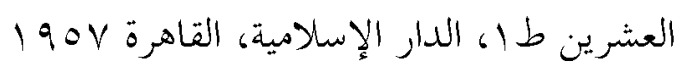

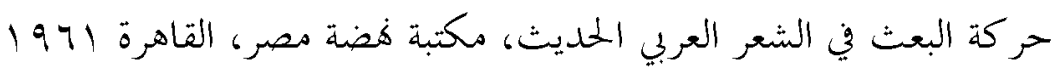

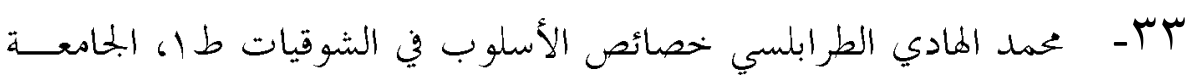

$$
\text { التو نسية }
$$

ع - - محمد حسن عبدالله الصورة والبناء الشعري دار المعارف القاهرة

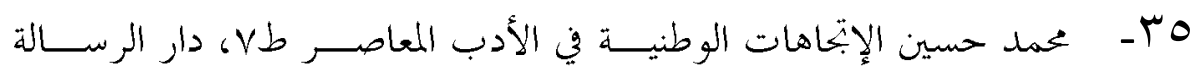

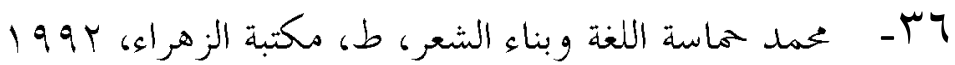
- MV

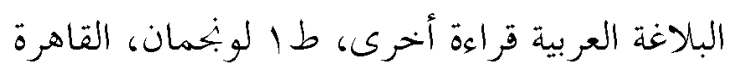

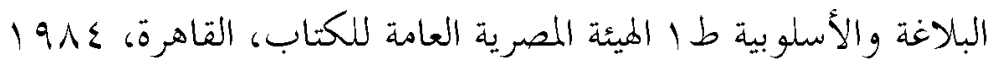
بناء الأسلوب في شعر الحماثة (التكوين البديعي) لوبخمان، القاهرة جدلية الإفراد والتركيب في النقد العربي، طاه لوبخمان، القاهرة

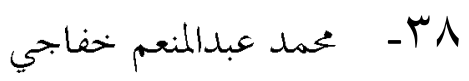

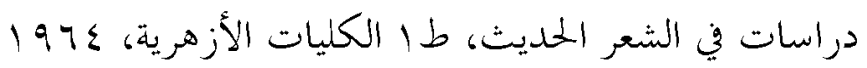

قصة الأدب في مصر، طا، دار الجميل بيروت، ب9 199

$$
\text { q" - محمد غنيمي هلال }
$$

النقد الأدبي الحديث، طب دار النهضة العربية، القاهرة، عـ197 197 •الرومانتيكية، ط ا، مكتبة هضة مصر، القاهرة

$$
\text { ح - } 2 \text {. }
$$

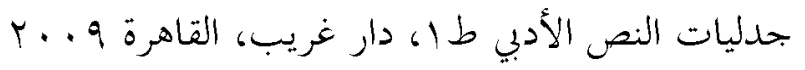




\section{لمـلم الموسيقى في شعر محمد الأسمر}

الرمز والرمزية في الشعر العربي الحديث، طلا، دار المعــــف، القـــاهرة

lavV

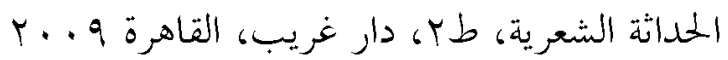

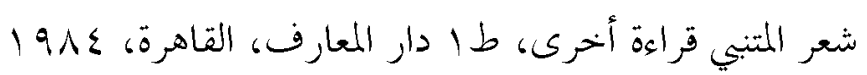

وقع القصيدة العربية، طا، دار المعارف، القاهرة، 9199

ر) - -

\section{الهوامش والإحالات}

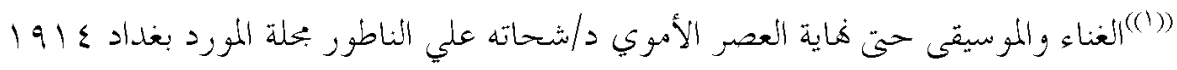

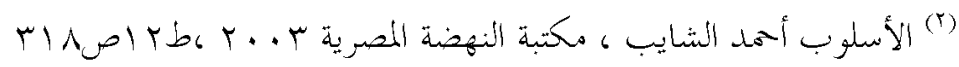

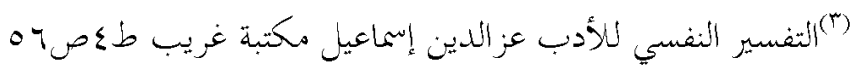

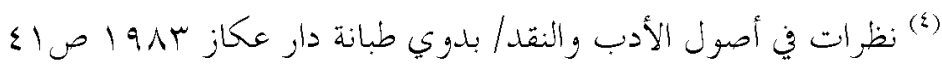

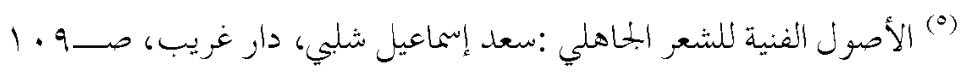

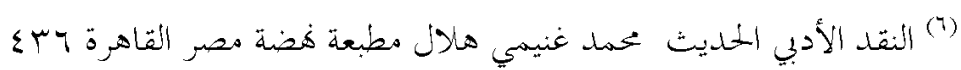

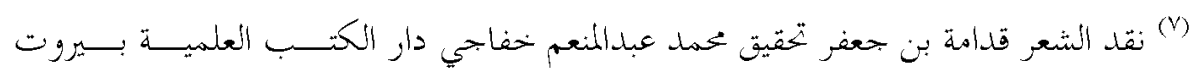

ص—

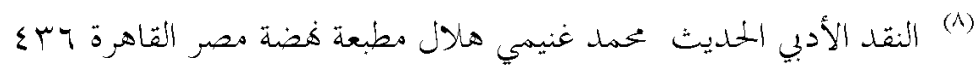

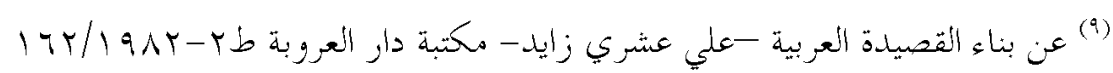

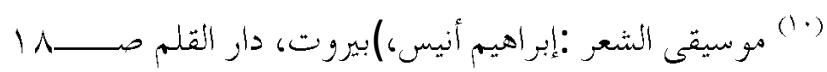

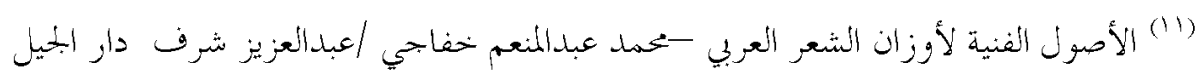

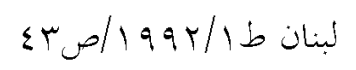

(1)

أن (r)

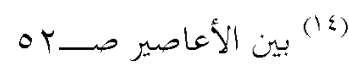

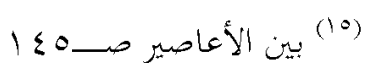




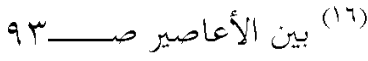

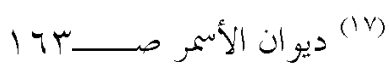

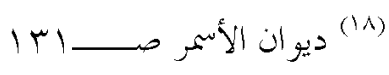

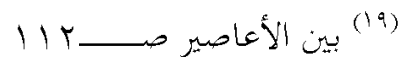

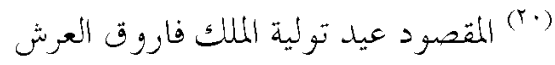

$$
\begin{aligned}
& \text { IVـ (Y) }
\end{aligned}
$$

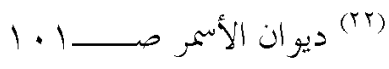

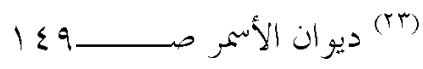

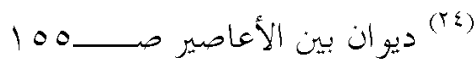

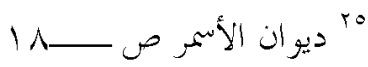

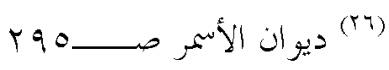

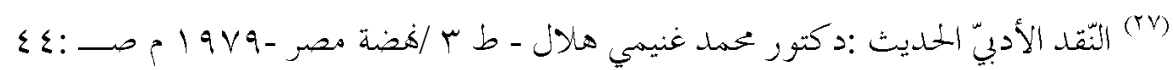
199 (r)

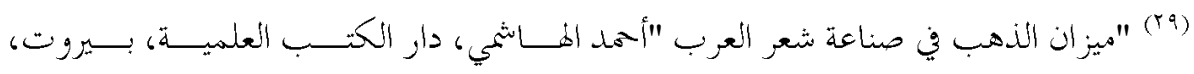

$$
\text { : } 112 \longrightarrow 1406
$$

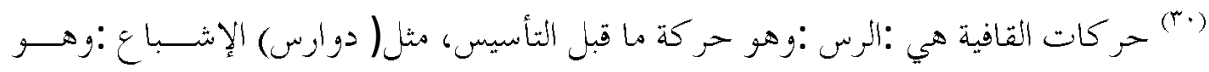

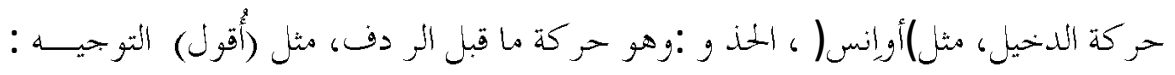
وهو حر كة ما قبل الروي المقيد، هثل ( الأمل ) الئرى "وهو حركة الروي المطلق، مثل طلعا النفا ذ :وهو حر كة الوحل إذا كان هاء، هثل :(شفاها )" ينظر " :أهدى سبيل إلى علمي

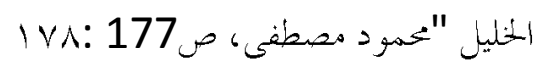

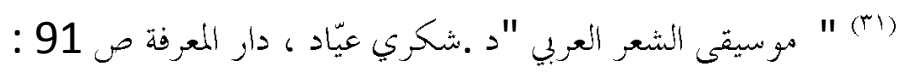

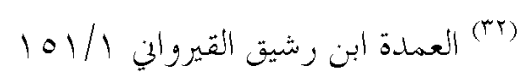

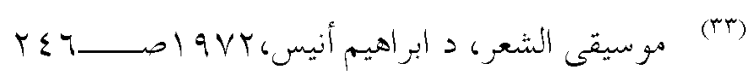

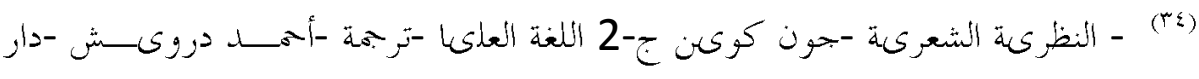

$$
\text { غرى }
$$




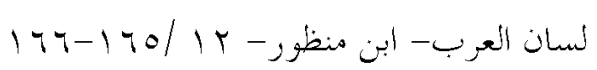

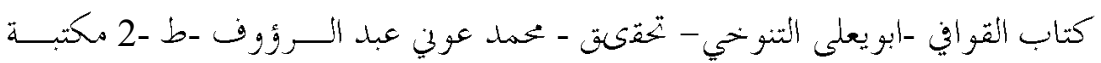

$$
\begin{aligned}
& \text { الخالبخي -القاهرة -مصر - } 1978 \text {-ص } 62
\end{aligned}
$$

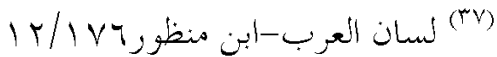

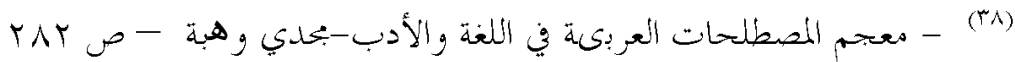

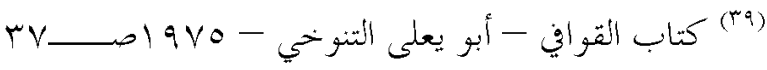

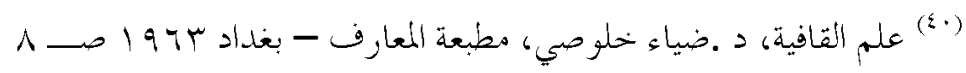

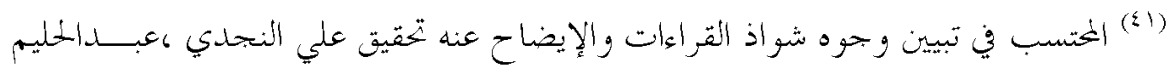

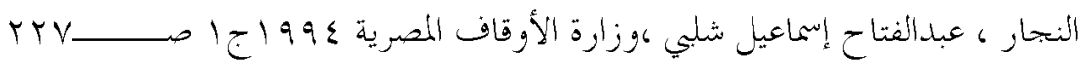

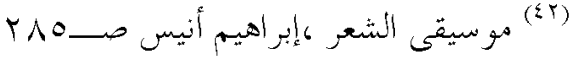

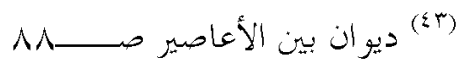

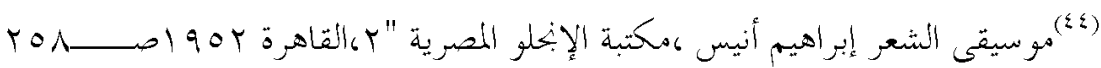

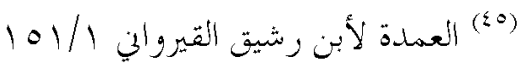

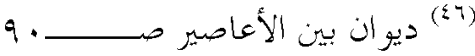

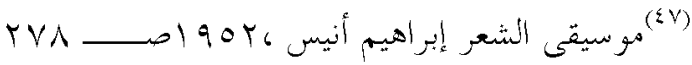

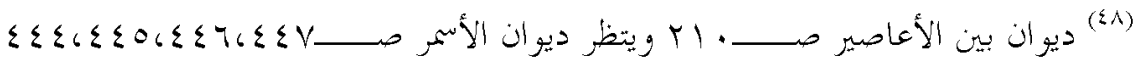

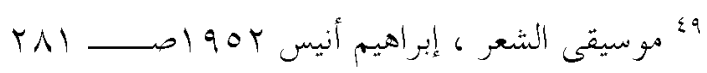

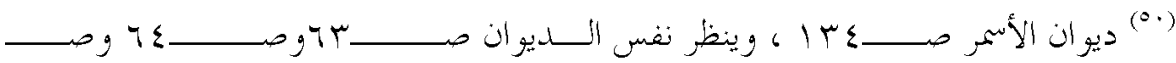

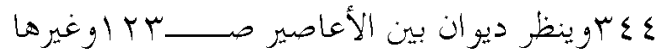

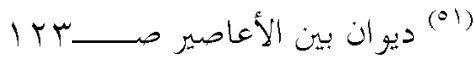

$$
\begin{aligned}
& \text { ¿ }
\end{aligned}
$$

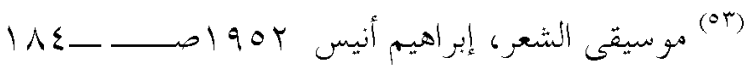

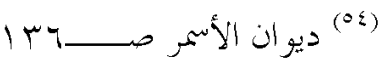

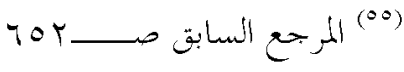


